\title{
CRFR1 activation protects against cytokine-induced $\beta$-cell death
}

\author{
Lykke Blaabjerg ${ }^{1,2, *}$, Gitte L Christensen ${ }^{2, *}$, Masahito Matsumoto', \\ Talitha van der Meulen', Mark O Huising ${ }^{1}$, Nils Billestrup ${ }^{2}$ and Wylie W Vale' \\ ${ }^{1}$ Clayton Foundation Laboratories for Peptide Biology, Salk Institute, 10100 North Torrey Pines Road, \\ La Jolla, California 92037, USA \\ ${ }^{2}$ Cellular and Metabolic Research Section, Department of Biomedical Sciences, Faculty of Health Sciences, \\ University of Copenhagen, Blegdamsvej 3, 2200 Copenhagen N, Denmark \\ *(L Blaabjerg and G L Christensen contributed equally to this work)
}

Correspondence should be addressed to L Blaabjerg

Email

lykke@blaabjerg.net

\begin{abstract}
During the development of diabetes $\beta$-cells are exposed to elevated concentrations of proinflammatory cytokines, TNF $\alpha$ and IL1 $\beta$, which in vitro induce $\beta$-cell death. The class B G-protein-coupled receptors (GPCRs): corticotropin-releasing factor receptor 1 (CRFR1) and CRFR2 are expressed in pancreatic islets. As downstream signaling by other class B GPCRs can protect against cytokine-induced $\beta$-cell apoptosis, we evaluated the protective potential of CRFR activation in $\beta$-cells in a pro-inflammatory setting. CRFR1/CRFR2 ligands activated AKT and CRFR1 signaling and reduced apoptosis in human islets. In rat and mouse insulin-secreting cell lines (INS-1 and MIN6), CRFR1 agonists upregulated insulin receptor substrate 2 (IRS2) expression, increased AKT activation, counteracted the cytokine-mediated decrease in BAD phosphorylation, and inhibited apoptosis. The anti-apoptotic signaling was dependent on prolonged exposure to corticotropin-releasing factor family peptides and followed PKA-mediated IRS2 upregulation. This indicates that CRFR signaling counteracts proinflammatory cytokine-mediated apoptotic pathways through upregulation of survival signaling in $\beta$-cells. Interestingly, CRFR signaling also counteracted basal apoptosis in both cultured INS-1 cells and intact human islets.
\end{abstract} Key Words
- $\beta$ cells
- apoptosis
- survival
- urocortins
- GPCR
- CRFR
- cytokines

\section{Introduction}

Pancreatic $\beta$-cell death occurs in type 1 as well as type 2 diabetes mellitus, leading to a progressive decline in $\beta$-cell function and $\beta$-cell mass. Although the initiating mechanism differs, some signaling pathways are relevant to both types of diabetes as they converge on common effectors. This is true for interleukin 1 beta (IL1 $\beta$ ) and tumour necrosis factor alpha (TNF $\alpha$ ) signaling, as both these pathways lead to the activation of two key proapoptotic signaling pathways in the $\beta$-cell, i.e. nuclear factor kappa B (NFאB) and MAPKs (Donath et al. 2003). Before cytokine exposure, $\mathrm{NF} \kappa \mathrm{B}$ is sequestered in the cytoplasm bound to inhibitor protein kappa $\mathrm{B} \alpha(\mathrm{I} \kappa \mathrm{B} \alpha)$. Following IL $1 \beta$ or TNF $\alpha$ exposure, I $\kappa \mathrm{B} \alpha$ is phosphorylated, ubiquitinated, and degraded by the proteasomal complex, liberating $\mathrm{NF} \kappa \mathrm{B}$ to translocate to the nucleus and induce the expression of several inflammatory genes (Baldwin et al. 1996, Flodstrom et al. 1996, Heimberg et al. 2001, Patel \& Santani 2009). Inhibition of the NFкB pathway protects pancreatic $\beta$-cells from cytokineinduced apoptosis in vitro and from multiple low-dose streptozotocin (STZ)-induced diabetes in vivo (Patel \& Santani 2009).

Published by Bioscientifica Ltd. 
The c-Jun N-terminal kinase (JNK) is a member of the MAPKs and an important mediator of cytokine-induced $\beta$-cell death. Blockage of JNK signaling protects against IL1 $\beta$-induced apoptosis in insulin-secreting cells (Ammendrup et al. 2000, Bonny et al. 2000, 2001, Nikulina et al. 2003) and prevents cytokine-induced suppression of viability in human islets (Aikin et al. 2004). Two other MAPKs, ERK1/2 and p38, have also been shown to be involved in the mediation of deleterious cytokine effects in $\beta$-cells (Pavlovic et al. 2000, Saldeen et al. 2001), although ERK1/2 may be more known for its proliferative capacity (Blandino-Rosano et al. 2008). The cross-talk between JNK and the serine/threonine kinase AKT has a great effect on the survival prospects of human islets (Aikin et al. 2004). AKT is widely involved in cell growth and survival and its importance in $\beta$-cell survival has been substantiated using various mouse models with transgenic modification of components of the AKT pathway (Elghazi \& Bernal-Mizrachi 2009). AKT is commonly activated in a phosphatidylinositol 3-kinase (PI3K)-dependent manner (Elghazi \& Bernal-Mizrachi 2009). The insulin receptor substrate 2 (IRS2), a substrate of the insulin/insulin-like growth factor signaling cascade responsible for compensatory $\beta$-cell growth, function, and survival throughout life (Jhala et al. 2003, White 2003), mediates anti-apoptotic signaling through the activation of AKT. A correlation between the increase in cAMP levels and the IRS2/AKT signaling pathway in $\beta$-cells has been demonstrated (Jhala et al. 2003, Van de Velde et al. 2011). AKT signaling inhibits several pro-apoptotic components including the JNK pathway (Aikin et al. 2004) and the pro-apoptotic BCL2 family member BAD (Zha et al. 1996). AKT-induced BAD phosphorylation is antagonized by JNK-stimulated BAD dephosphorylation. The latter leads to BAD-mediated functional blockage of anti-apoptotic BCL-XL and BCL2, initiation of the caspase cascade, and induction of $\beta$-cell death (Zha et al. 1996, Sunayama et al. 2005).

The corticotropin-releasing factor (CRF) family of peptides includes CRF, and urocortin (UCN) 1, 2, and 3 (Vaughan et al. 1995, Perrin \& Vale 1999, Reyes et al. 2001, Lewis et al. 2001). These peptides bind to the two subtypes of CRF receptors, corticotropin-releasing factor receptor 1 (CRFR1) and CRFR2, with varying affinity. CRF is a preferred CRFR1 agonist (Perrin \& Vale 1999) in contrast to UCN2 and UCN3, which are selective CRFR2 agonists (Hsu \& Hsueh 2001, Lewis et al. 2001, Reyes et al. 2001). UCN1 binds to both receptors with high affinity (Perrin \& Vale 1999). The members of this family were initially recognised as coordinators of the mammalian stress response. Since then, these peptides as well as their receptors have been identified in many tissues throughout the periphery, indicating a potential involvement in other physiological responses (Kimura et al. 2002, Florio et al. 2004, Fekete \& Zorrilla 2007, Kuperman \& Chen 2008, Lee et al. 2011). In fact, the pancreatic $\beta$-cell is one of the most abundant sites of UCN3 expression ( $\mathrm{Li}$ et al. 2003).

Pancreatic islets were recently found to express both CRFR1 and CRFR2 in equal abundance (Huising et al. 2011). In clonal $\beta$-cells, such as MIN6 and INS- 1 cells, the expression levels of CRFR1 are much higher than those of CRFR2, a balance that can be overturned by exposure to glucocorticoids (Huising et al. 2010, 2011). These receptors belong to the class B G-protein-coupled receptors (GPCRs), as do receptors for incretins such as glucose-dependent insulinotropic polypeptide (GIP) and glucagon-like peptide1 (GLP1) (Brubaker \& Drucker 2002). This subclass of receptors couples with $\mathrm{G} \alpha \mathrm{s}$ and activates adenylate cyclase to stimulate cAMP production. We have previously shown that CRFR1 activation increases insulin secretion from the pancreatic islets (Huising et al. 2010). The signaling induced by GIP and GLP1 is known to prevent cytokineinduced apoptosis in $\beta$-cells (Li et al. 2005, Ferdaoussi et al. 2008, Natalicchio et al. 2010), prompting us to investigate the potential of CRFR signaling to promote $\beta$-cell survival and to protect against cytokine-induced $\beta$-cell death.

\section{Materials and methods}

\section{Reagents}

Recombinant murine IL1 $\beta$ was purchased from BD Pharmingen (San Diego, CA, USA) and mouse TNF $\alpha$ from R\&D Systems (Minneapolis, MN, USA). Antalarmin was a kind gift from Dr Chrousos at the NIH. All peptides used in this study were synthesized using BOC chemistry and provided by Dr Jean Rivier (The Salk Institute, La Jolla, CA, USA). LY294002 and H89 were obtained from Calbiochem (Billerica, MA, USA).

\section{Cells}

INS-1 cells and MIN6 insulinoma cells (obtained at passage 18 from Ulupi Jhala (UCSD, La Jolla, CA, USA) were maintained in DMEM (Invitrogen), containing Glutamax and $11 \mathrm{mM}$ of glucose and supplemented with 10\% FBS (Sigma), $100 \mathrm{U} / \mathrm{ml}$ penicillin, $100 \mu \mathrm{g} / \mathrm{ml}$ streptomycin (Invitrogen), and $10 \mu \mathrm{mol} / 1 \beta$-mercaptoethanol(Sigma). The cells were cultured under standard cell culture conditions at $37^{\circ} \mathrm{C}$ in a humidified atmosphere containing $5 \% \mathrm{CO}_{2}$.

Published by Bioscientifica Ltd. 


\section{Human islets}

Human islets were obtained through the Integrated Islet Distribution Program (IIDP islet program) funded by the National Institute of Diabetes and Digestive and Kidney Diseases (NIDDK) and with support from the Juvenile Diabetes Research Foundation International (JDRFI). Upon arrival, islets were washed twice in CMRL with $10 \%$ FBS, $100 \mathrm{U} / \mathrm{ml}$ penicillin, and $100 \mu \mathrm{g} / \mathrm{ml}$ streptomycin (Invitrogen). The islets were re-picked and cultured for 1-2 days before an experiment was set up.

\section{Immunoblotting}

One hundred human islets were seeded into 24-well plates (Nunc, Rochester, NY, USA) or 400000 INS-1 cells were seeded into 12-well plates. The receptor antagonists were added $30 \mathrm{~min}$ before peptides and cells/islets were incubated for various times (30 min to $24 \mathrm{~h}$ ). The cytokines were added $16 \mathrm{~h}$ following peptide treatment and cultured continued for another $20 \mathrm{~min}$ to $24 \mathrm{~h}$. The cells were lysed in PLC-lysis buffer (50 mM HEPES $(\mathrm{pH}$ 7.5), $150 \mathrm{mM} \mathrm{NaCl}, 10 \%$ glycerol, 1\% Triton X-100, $1.5 \mathrm{mM} \mathrm{MgCl}_{2}, 1 \mathrm{mM}$ EGTA, $100 \mathrm{mM}$ Naf, $10 \mathrm{mM}$ NaPPi, $50 \mu \mathrm{M} \mathrm{NaVO}$, supplemented with protease inhibitors (Roche Diagnostics) and $1 \mathrm{mM}$ dithiothreitol (DTT)). The protein content was measured by the Bradford method before proteins were separated by gel electrophoresis using 3-7 or $10 \%$ BisTris gels (Invitrogen) and transferred by electroblotting to nitrocellulose membranes (Invitrogen). The membranes were blocked using Tris buffered saline with Tween (TBST) buffer $(50 \mathrm{mM}$ Tris$\mathrm{HCl}$ (pH 7.4), $150 \mathrm{mM} \mathrm{NaCl}$, and $0.1 \%$ Tween 20 containing 5\% nonfat dried milk) and incubated with a primary antibody overnight at $4{ }^{\circ} \mathrm{C}$. After washing in TBST, the membranes were incubated with secondary antibody at room temperature. Antibodies: Active motif; IкB $\alpha$ (\#40903) (Cell Signaling, Beverly, MA, USA); phospho-ERK1/2 (\#4377), total ERK1/2 (\#9102), phospho-p38 (\#4511), phospho-JNK (\#4668), phospho-AKT (\#9271), total AKT, cleaved caspase 3 (\#9661), and phospho-BAD (\#4366) (BD Pharmingen); iNOS (\#610332) (Santa Cruz Biotechnology); total JNK1 (\#Sc571) and IRS2 (\#Sc-1555) (Millipore, Bedford, MA, USA); IRS2 (\# MABS15) (Abcam, Cambridge, MA, USA); $\beta$-actin (ab6276). The secondary antibodies include HRP conjugated donkey anti rabbit or sheep anti mouse (GE Healthcare, Bucks, UK) and rabbit anti goat (Thermo Scientific Pierce, Rockford, IL, USA). The immunecomplexes were detected using a chemiluminescent substrate (Thermo Scientific Pierce), and light emission was captured using film (Kodak).

\section{Gene reporter assay}

Two hundred thousand INS-1 cells were seeded in triplicates into 24-well dishes and preincubated for 2 days. On the day of transfection, the medium was discarded and the cells transiently co-transfected with a total of $0.7 \mu \mathrm{g}$ plasmid DNA using Lipofectamin 2000 (Invitrogen): NFкB-dependent expression plasmid (Strategene, Santa Clara, CA, USA) together with a $\beta$-galactosidase expression plasmid for normalization. Following $6 \mathrm{~h}$ of transfection, the media was replaced and cells were cultured overnight before the addition of cytokines for $4 \mathrm{~h}$. The cells were subsequently washed in HDB and lysed in Gly-Gly buffer (25 mM Gly-Gly (pH 7.5), $15 \mathrm{mM} \mathrm{MgSO}_{4}, 4 \mathrm{mM}$ EGTA), with the addition of $10 \%$ Triton X-100 and $1 \mathrm{mM}$ DTT. At the time of measurements, the samples were diluted in Gly-Gly buffer including $10 \mathrm{mM}$ potassium phosphate, $1.25 \mathrm{mM}$ DTT, and $1.25 \mathrm{mM}$ ATP. Luciferase activity was detected by adding Gly-Gly buffer containing $0.1 \mathrm{mM}$ luciferase and read using a Modulus plate reader. Consecutively, $\beta$-galactosidase buffer $(0.875 \mathrm{mg} / \mathrm{ml}$ O-nitrophenyl- $\beta$-Dgalactoside (ONPG) in sodium phosphate, $100 \mathrm{mM}$ sodium phosphate $\mathrm{pH} 7.5,0.3 \% \quad \beta$-mercaptoethanol, $1 \mathrm{mM} \mathrm{MgCl}_{2}$ ) was added and cells were incubated until a color change was observed and the absorbance was be measured at $450 \mathrm{nM}$.

\section{Cell death detection ELISA}

Sixty human islets or 200000 INS-1 cells were seeded in 24-well plates. Following pre-treatment with peptides, cells or islets were cultured in the presence or absence of cytokines for 6 days or $24 \mathrm{~h}$ respectively. The degree of apoptosis was measured by cell death detection ELISA plus (Roche) according to the manufacturer's instructions, detecting the amount of DNA-histone complexes present in the cytoplasmic lysates.

\section{Statistical analyses}

All data are presented as mean \pm s.E.M. of $n$ independent experiments. Statistical analysis was performed using a paired Student's $t$-test or a one-way ANOVA followed by post hoc Dunnett multiple comparison analysis where appropriate. A $P$ value $<0.05$ was considered significant.

Published by Bioscientifica Ltd. 
(a)
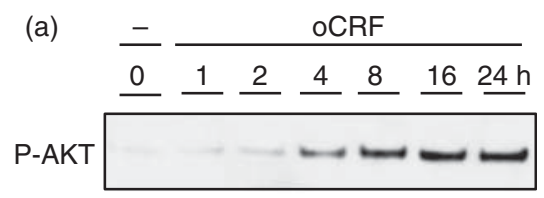

T-AKT

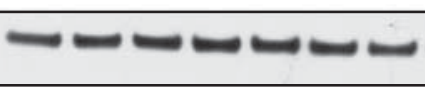

(b)

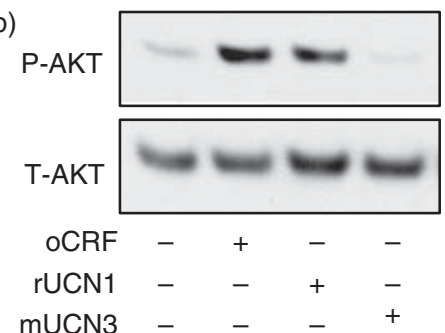

(c)

P-AKT

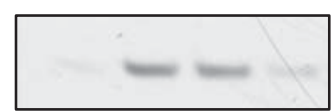

T-AKT

oCRF

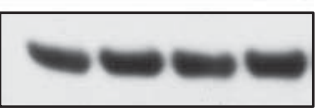

rUCN1

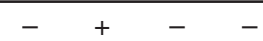

mUCN3

$\begin{array}{llll}- & + & - & - \\ - & - & + & -\end{array}$

\section{Figure 1}

Effect of CRFR signaling on AKT activation. INS-1 cells (a) were treated with $50 \mathrm{nM}$ of oCRF for various times ranging from 1 to $24 \mathrm{~h}$. The lysates were subjected to immunoblotting using antibodies against phosphorylated (P-AKT) or total AKT (T-AKT). A representative blot is shown $(n=3)$. INS-1 cells (b) or MIN6 cells (c) were treated with $50 \mathrm{nM}$ of oCRF, rUCN1, or mUCN3 for $16 \mathrm{~h}$ and lysates were treated as above $(n=4)$.

\section{Results}

\section{CRF family members differentially activate AKT in $\beta$-cells}

AKT has previously been shown be involved in $\beta$-cell survival signaling mediated by class B GPCRs, and we investigated whether members of the CRF family could affect AKT activity in $\beta$-cells. INS- 1 cells were treated with the CRFR1-selective agonist, ovine CRF (oCRF), for various times ranging from 0 to $24 \mathrm{~h}$. A time-dependent increase in phoshorylation of AKT, peaking at around $16 \mathrm{~h}$ of oCRF exposure was demonstrated (Fig. 1a). The experiment was repeated using either mouse UCN3 (mUCN3) or rat UCN1 (rUCN1) to activate either CRFR2 alone or both CRFR1 and CRFR2, simultaneously. Exposure of cells to rUCN1 for $16 \mathrm{~h}$ robustly upregulated the levels of phosphorylated AKT compared with untreated cells, as seen for oCRF (Fig. 1b and c for rat INS-1 and mouse MIN6 cells, respectively). In contrast no effect was observed with mUCN3.

\section{CRFR1-mediated upregulation of IRS2 and PI3K-dependent activation of AKT in $\beta$-cells}

$\beta$-cells, as opposed to intact islets, mainly express CRFR1 and pre-incubating the cells with $10 \mu \mathrm{M}$ of the CRFR1selective antagonist antalarmin fully blocked both basal and oCRF- and rUCN1-mediated phosphorylation of AKT, suggesting that this is a CRFR1-mediated effect (Fig. 2a).

As PI3K is a common upstream activator of AKT, we used LY2940002, a pharmacological inhibitor of PI3K signaling, to investigate whether PI3K was involved in AKT activation in our cell systems. As evident from Fig. 2b, pre-incubation with $10 \mu \mathrm{M}$ of LY294002 fully inhibited oCRF- and rUCN1-mediated phosphorylation of AKT. In addition, we found that oCRF dose-dependently affected transcription of a glucose-6-phosphatase promoter construct in a luciferase assay, a promoter previously reported to be responsive to the activation of the AKT signaling pathway (Schmoll et al. 2000; Fig. 2c), further confirming activation of the AKT pathway.

CRFR1 activation did not lead to acute activation of AKT in $\beta$-cells (Fig. 1), indicating that the observed effects are dependent on another factor. IRS2 is thought to promote islet cell survival in response to insulin and IGFI signaling (Withers et al. 1999, Fernández et al. 2007) and may act upstream of PI3K (Jhala et al. 2003). To investigate if CRFR1 agonists could increase IRS2 expression in $\beta$-cells, INS- 1 cells were treated with oCRF or rUCN1 for various times, ranging from $30 \mathrm{~min}$ to $24 \mathrm{~h}$. From the results of this experiment, we conclude that CRFR1 activation leads to increased protein levels of IRS2, peaking at around $8 \mathrm{~h}$ of treatment (Fig. 2d). Pre-treating the cells with $10 \mu \mathrm{M}$ of H89, a pharmacological inhibitor of the cAMP-dependent protein kinase A (PKA), before exposure to the CRFR1 ligands revealed partial inhibition of oCRF- or rUCN1induced upregulation of IRS2 protein expression and AKT phosphorylation (Fig. 2e). Together these results indicate that CRFR1-mediated PKA-dependent upregulation of IRS2 precedes AKT activation.

\section{CRFR1 activation increases survival signaling in cytokine-exposed $\beta$-cells}

The pro-inflammatory cytokines IL1 $\beta$ and TNF $\alpha$ have been shown to induce apoptosis by inhibiting the activity of AKT. As seen in Fig. 3a, exposure to IL1 $\beta(160 \mathrm{pg} / \mathrm{ml})$ or $\mathrm{TNF} \alpha(20 \mathrm{ng} / \mathrm{ml})$ for $24 \mathrm{~h}$ reduced the levels of phosphorylated AKT compared with those for untreated INS-1 cells. To examine if CRFR1 activation preserves AKT activity in the presence of cytokines, INS-1 cells were

Published by Bioscientifica Ltd 
pre-treated with oCRF, rUCN1, or mUCN3 for $16 \mathrm{~h}$, followed by exposure to IL1 $\beta$ or TNF $\alpha$. Cytokine-induced reduction of phosphorylated AKT was counteracted by pre-treatment with either oCRF or rUCN1. In line with previous observations, we did not observe any protection

(a)

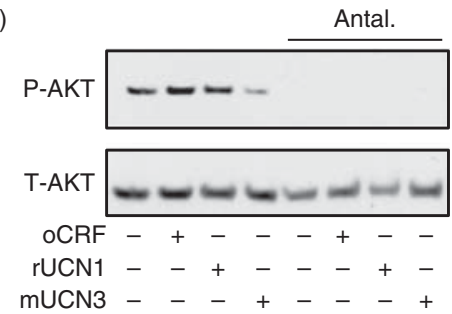

(b)

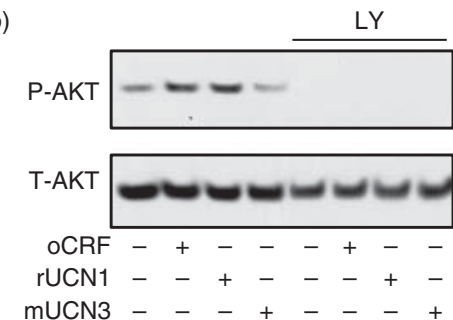

(c)

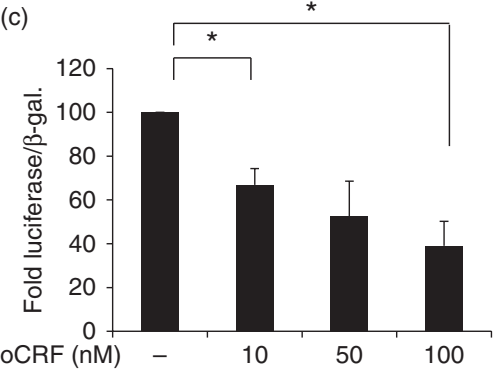

(d)
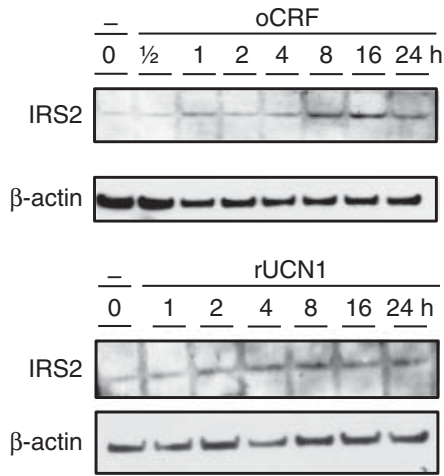

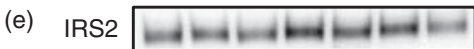

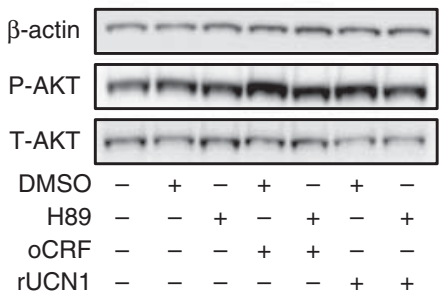

http://jme.endocrinology-journals.org DOI: 10.1530/JME-14-0056

(c) 2014 Society for Endocrinology Printed in Great Britain against the cytokine-mediated decrease in AKT phosphorylation with mUCN3 treatment.

One mechanism by which AKT promotes survival is by phosphorylation-induced inactivation of the proapoptotic BAD. Indeed, exposure of INS-1 cells to TNF $\alpha$ partly reduced the levels of phosphorylated BAD compared with untreated INS-1 cells (Fig. 3b) and as for AKT, cytokine-mediated reduction in phosphorylated $\mathrm{BAD}$ was counteracted by pre-culturing the cells in the presence of oCRF or rUCN1 but not by mUCN3. A similar effect was seen after exposure of INS-1 cells to IL1 $\beta$ or MIN6 cells to a combination of IL1 $\beta$ and TNF $\alpha$ (data not shown). We thus conclude that CRFR1 agonists can increase survival signaling and inhibit cytokine-mediated apoptosis.

\section{CRFR1 activation counteracts pro-apoptotic signaling in cytokine-exposed $\beta$-cells}

The MAPKs are activated by cytokines such as IL1 $\beta$ and TNF $\alpha$. To explore any potential effects of CRFR activation on MAPK activity, INS-1 cells were pre-treated with CRF family members as described above and subsequently exposed to either IL1 $\beta$ or TNF $\alpha$ for an additional 20 min. Western blotting results represented in Fig. 4a indicate that, as expected, cytokines activated all three MAPKs. Neither peptide inhibited MAPK phosphorylation, but interestingly cytokine-induced ERK1/2 phosphorylation was potentiated in cells pre-treated with oCRF or rUCN1. No effect was seen for mUCN3.

\section{Figure 2}

Determination of receptor type and signaling components. (a) INS- 1 cells were treated with $5 \mu \mathrm{M}$ of the CRFR1 antagonist, antalarmin (Antal) $30 \mathrm{~min}$ before addition of $50 \mathrm{nM}$ of OCRF, rUCN1, or mUCN3 and cultured for $16 \mathrm{~h}$. The lysates were analysed by immunoblotting using antibodies against phosphorylated (P-AKT) or total AKT (T-AKT). A representative blot is shown $(n=4)$. (b) INS-1 cultured with $10 \mu \mathrm{M}$ of the PI3K inhibitor LY294002 (LY) 30 min before treatment with oCRF, rUCN1, or mUCN3 and handled as above. (c) INS-1 cells were transiently transfected with a glucose-6phosphatase promotor construct, leading to luciferase expression, and a constitutively active $\beta$-galactosidase construct. The cells were cultured with increasing concentration of oCRF. Data are presented as mean luciferase activity normalised to $\beta$-galactosidase \pm S.E.M. from three independent experiments each performed in triplicates. ${ }^{\star} P<0.05$ vs untreated cells ( $t$-test). (d) INS-1 cells were treated with $50 \mathrm{nM}$ of oCRF or rUCN1 for various time points ranging from $30 \mathrm{~min}$ to $24 \mathrm{~h}$. The lysates were subjected to immunoblotting using antibodies against IRS2 and the housekeeping protein $\beta$-actin. A representative blot from one of three independent experiments is shown $(n=3)$. (e) INS- 1 cells were pre-treated with $10 \mu \mathrm{M}$ of $\mathrm{H} 89$ for $30 \mathrm{~min}$ before addition of $50 \mathrm{nM}$ of oCRF or rUCN1 and culture for additional $16 \mathrm{~h}$. The lysates were analysed for IRS2 expression, $\beta$-actin, phosphorylated AKT (P-AKT), and total AKT (T-AKT). The blot shown is representative of results from three independent experiments $(n=3)$.

Published by Bioscientifica Ltd. 

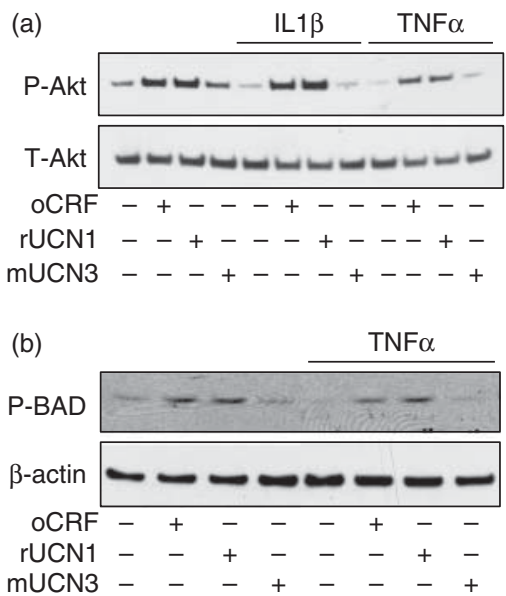

\section{Figure 3}

Effect of CRFR signaling on survival pathways. (a) INS-1 cells were pre-cultured with oCRF, rUCN1, or mUCN3 for $16 \mathrm{~h}$. Subsequently, IL1 $\beta$ $(160 \mathrm{pg} / \mathrm{ml})$ or TNF $\alpha(20 \mathrm{ng} / \mathrm{ml})$ was added to the cells and culture was continued for another $24 \mathrm{~h}$. The cell extract was analysed for phosphorylated (P-AKT) or total (T-AKT) AKT by western blotting analysis.

A representative blot is shown $(n=5)$. (b) INS-1 cells were pre-treated as described above and exposed to TNF $\alpha$ for $24 \mathrm{~h}$. Levels of phosphorylated $B A D$ and $\beta$-actin were analysed by western blotting analysis. A representative blot from one of three independent experiments is shown $(n=3)$.

Taking advantage of an NFkB-reporter construct, we looked at NFkB-mediated gene regulation. As expected, both IL1 $\beta$ and TNF $\alpha$ significantly increased NFKB promoter activity in INS-1 cells (Fig. $4 \mathrm{~b}$ ). The cells pretreated with oCRF exhibited lesser cytokine-mediated increases in promoter activity, indicating that CRFR1 activation can affect cytokine-induced NFкB-mediated gene regulation. TNF $\alpha$ and IL1 $\beta$ increase NFKB transcriptional activity by promoting I $\mathrm{B} \alpha \alpha$ degradation. However, neither peptide was able to inhibit this cytokine-induced degradation of $I \kappa B \alpha$, indicating that CRF family members do not exert their modulation of NFאB signaling by affecting I $\kappa \mathrm{B} \alpha$ directly (Fig. $4 \mathrm{c}$ ). Similar results were obtained using MIN6 cells (data not shown).

\section{CRFR1 activation prevents cytokine-induced apoptosis}

As CRFR1 activation affects key survival and apoptotic pathways, we next explored the effect of cytokines and the CRF family members on cleavage of the executor caspase 3. Stimulation with a combination of IL1 $\beta$ and TNF $\alpha$ resulted in the cleavage of caspase 3 (Fig. 5 a). We found that pre-treatment with either oCRF or rUCN1 but not mUCN3 reduced this cytokine-mediated cleavage of caspase 3, supporting the concept that activation of the CRFR1 protects against cytokine-induced $\beta$-cell death.

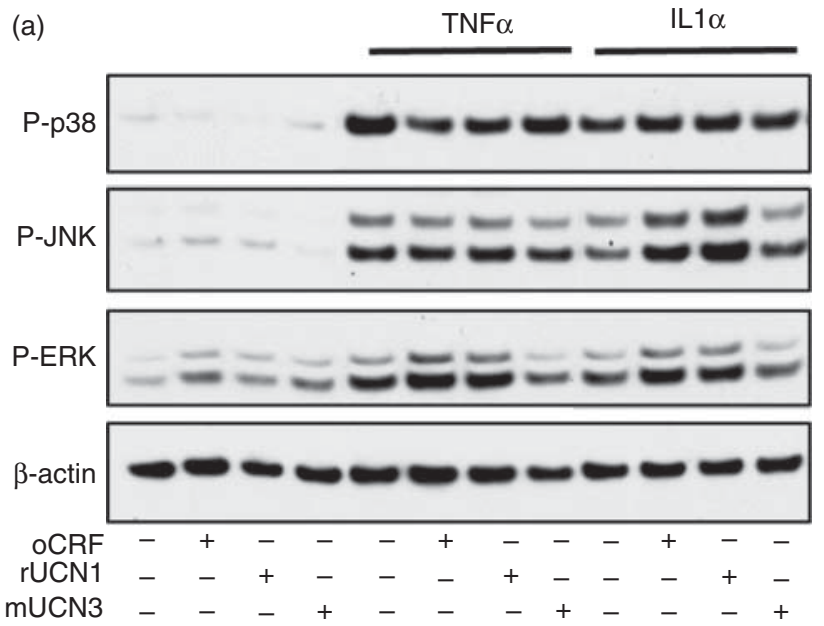

(b)

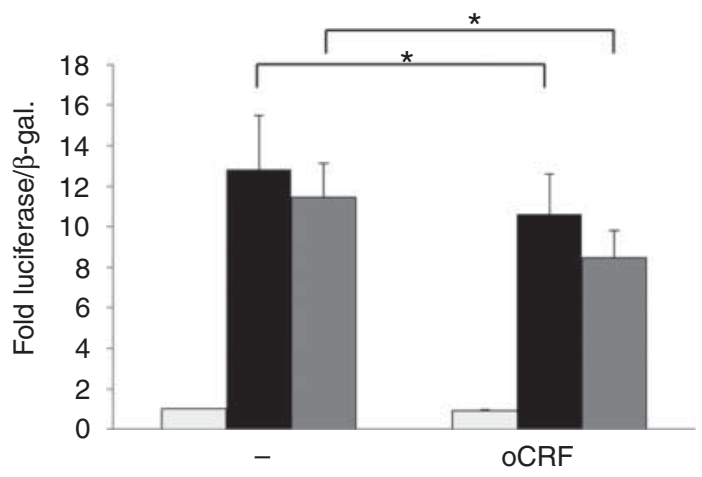

(c)
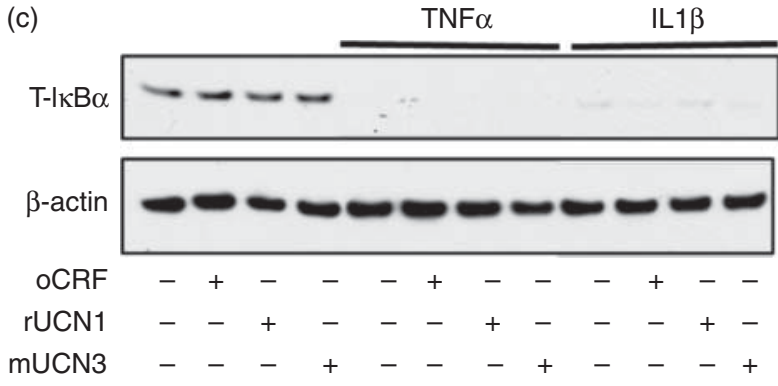

\section{Figure 4}

Effect of CRFR signaling on cytokine-induced MAPK and NFKB activation. (a) INS-1 cells were pre-cultured with oCRF, rUCN1, or mUCN3 for $16 \mathrm{~h}$ followed by IL1 $\beta(160 \mathrm{pg} / \mathrm{ml})$ or TNF $\alpha(20 \mathrm{ng} / \mathrm{ml})$ exposure for an additional $20 \mathrm{~min}$. The cell extracts were analysed for phosporylated (P) JNK, p38, and ERK 1/2. A representative blot from three independent experiments is shown $(n=3)$. (b) INS-1 cells were transiently co-transfected with an $\mathrm{NF} \kappa \mathrm{B}$-responsive reporter construct together with a constitutively active $\beta$-galactosidase construct, incubated with oCRF for $16 \mathrm{~h}$ and exposed to IL $1 \beta$ or TNF $\alpha$ for another $6 \mathrm{~h}$. Data are presented as mean luciferase activity normalised to $\beta$-galactosidase \pm S.E.M. from four independent experiments each carried out in triplicates $(n=4) . * P<0.05$ vs cytokine-treated cells (t-test). White bars represent controls, black bars IL $1 \beta$-treated, and grey bars TNF $\alpha$-treated cells. (c) INS-1 cells were treated as described above and degradation of $I_{\kappa} B \alpha$ was analysed by western blotting analysis using the whole-cell lysates and antibodies against $I_{\kappa} B \alpha$ and the housekeeping protein $\beta$-actin. A representative blot from one of three independent experiments is shown $(n=3)$. http://jme.endocrinology-journals.org DOI: 10.1530/JME-14-0056
(C) 2014 Society for Endocrinology Printed in Great Britain 
(a)

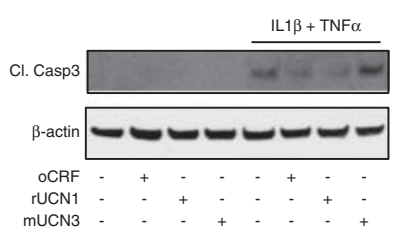

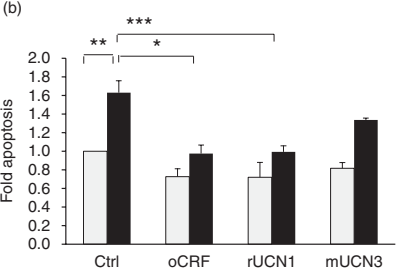
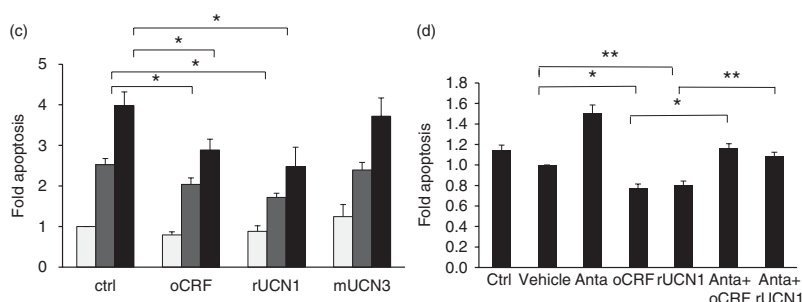

Figure 5

Effects of CRFR1 signaling on cytokine-induced apoptosis. (a) MIN6 cells were pre-treated with $50 \mathrm{nM}$ of oCRF, rUCN1, or mUCN3 for $16 \mathrm{~h}$. Subsequently cells were exposed to IL $1 \beta(160 \mathrm{pg} / \mathrm{ml})$ in combination with TNF $\alpha$ for $24 \mathrm{~h}$. Following lysis, western blotting was carried out and apoptosis was detected by antibodies recognising the cleaved form of caspase 3 as well as $\beta$-actin. A representative blot from one of three independent experiments is shown $(n=3)$. (b) INS- 1 cells were pre-treated as described for (a) subsequently TNF $\alpha(20 \mathrm{ng} / \mathrm{ml})$ or was added and cells were cultured for another $24 \mathrm{~h}$. (c) MIN6 cells were treated as described

To confirm this, we evaluated $\beta$-cell apoptosis in the form of DNA double-stranded breaks by using the cell death detection ELISA assay. This assay revealed an increase in apoptosis in INS-1 cells following TNF $\alpha$ exposure for $24 \mathrm{~h}$. Pre-treating the cells with either oCRF or rUCN1 completely blocked TNF $\alpha$-induced apoptosis (Fig. 5b). Similarly, oCRF or rUCN1 but not mUCN3 significantly inhibited IL1 $\beta$ - or TNF $\alpha$-induced apoptosis in MIN6 cells (Fig. 5c). Taking a closer look at basal apoptosis, oCRF and rUCN1 also inhibited basal apoptosis in INS-1 cells (Fig. 5d). This effect was counteracted by $30 \mathrm{~min}$ pretreatment with the CRFR1-selective antagonist antalarmin (Fig. 5d).

\section{CRFR1 and CRFR2 activation promote basal survival of human islets}

The effect of CRFR1 and CRFR2 activation was investigated in human islets from three individual donors. Intact human islets were cultured in the presence of oCRF, rUCN1, or hUCN3 and cell lysates analysed for phosphorylation of AKT. As is evident from Fig. 6a, AKT phosphorylation was apparent in response to both CRFR1 and CRFR2 ligands following 8-16 h of treatment (Fig. 6a).

In human islets from one donor oCRF, rUCN1, or hUCN3 reduced apoptosis induced by a combination of IL1 $\beta, \mathrm{TNF} \alpha$, and IFN $\gamma$ by 49,17 , and $42 \%$ respectively (data not shown). In experiments using islets from two other donors, cytokines induced substantially more apoptosis, which could not be inhibited by the CRF family members tested (data not shown). However, in islets from all three donors, basal apoptosis levels in freshly isolated above and exposed to IL1 $\beta(160 \mathrm{pg} / \mathrm{ml})$ or TNF $\alpha(20 \mathrm{ng} / \mathrm{ml})$ for $24 \mathrm{~h}$. (d) INS-1 cells were pretreated with vehicle $(\mathrm{EtOH})$ or $5 \mu \mathrm{M}$ antalarmin for $30 \mathrm{~min}$ before stimulation with $50 \mathrm{nM}$ oCRF or rUCN1 for $60 \mathrm{~h}$. Apoptosis was detected by cell death detection ELISA and data are presented as mean fold induction of apoptosis \pm s.E.M. from three to four independent experiments ( $n=3-4) .{ }^{*} P<0.05, * * P<0.01, * * * P<0.001$ vs cytokine-stimulated cells ( $t$-test). White bars represent controls, black bars TNF $\alpha$-treated cells, and grey bars IL $1 \beta$-treated cells.

human islets were significantly reduced when cultured in the presence of oCRF or rUCN1 (Fig. 6b). Human UCN3 did not significantly reduce apoptosis $(P=0.06)$. These results indicate that the CRFR1-selective agonists can activate AKT and inhibit apoptosis in cultured human islets.

\section{Discussion}

In this study, we characterized CRFR signaling in $\beta$-cells and examined the role of CRF family members in cytokine-induced $\beta$-cell apoptosis. Signaling through
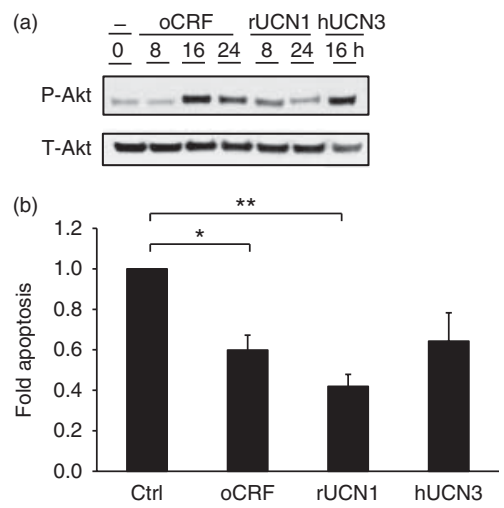

\section{Figure 6}

Effect of CRFR signaling on human islets. (a) Human islets were pre-treated with $50 \mathrm{nM}$ of oCRF, rUCN1, or hUCN3 as indicated and analysed for levels of phosphorylated AKT (P-AKT) or total AKT (T-AKT) by western blotting analysis. A representative blot from one of three independent experiments is shown $(n=3)$. (b) Human islets were pre-treated as described above and cultured for 6 days. Apoptosis was determined by the cell death detection ELISA. Experiment was carried out independently on islets from three different donors and data are presented as mean apoptosis \pm S.E.M. ${ }^{*} P<0.05, * * P<0.01$ vs untreated islets ( $t$-test) $(n=3)$. http://jme.endocrinology-journals.org DOI: 10.1530/JME-14-0056
(C) 2014 Society for Endocrinology Printed in Great Britain 
CRFR1 and CRFR2 protects cultured hippocampal and neocortical neurons from a range of neurotoxic mediators (Facci et al. 2003) and positively affects survival of cardiac myocytes in the models of heart failure (Brar et al. 2000, 2002). Recently, CRF has been shown to inhibit basal apoptosis in INS-1 cells following $72 \mathrm{~h}$ of culture, but the underlying mechanisms were not investigated (Schmid et al. 2011). In this study, we confirm this observation using both cell lines and human islets and demonstrate for the first time, to our knowledge, the ability of the CRF family members to protect $\beta$-cells against apoptotic stimuli associated with the development of diabetes.

Inhibition of pro-apoptotic $\mathrm{NF} \kappa \mathrm{B}$ signaling was apparent as CRFR1 activation reduced NFкB-mediated gene transcription induced by either TNF $\alpha$ or IL1 $\beta$. No effect was seen on I $\mathrm{B} \alpha \alpha$ degradation. The ability of $\mathrm{NF} \kappa \mathrm{B}$ to recruit the transcriptional apparatus and stimulate target gene expression in the nucleus is ensured by post-translational modification (i.e., phosphorylation, acetylation, etc.) of $\mathrm{NF \kappa B}$ itself and its surrounding chromatin environment. CRFR1 agonists may inhibit NFкB-mediated gene transcription by preventing crucial post-translational modifications, although this has not been investigated further.

In addition, CRFR1 signaling prevented the cytokinemediated decrease in AKT phosphorylation as well as dephosphorylation of the AKT target BAD, all favoring survival.

A time-course experiment revealed that a prolonged exposure (16 h) to CRFR1 ligands was required for robust activation of AKT in $\beta$-cells. This is in line with what has been reported for GLP1-receptor-mediated AKT activation in MIN6 cells and human islets. The proposed mechanism involved is a cAMP/PKA and CREB-dependent upregulation of IRS2 protein levels working upstream of PI3K (Jhala et al. 2003, Li et al. 2005, Park et al. 2006, Altarejos \& Montminy 2011, Van de Velde et al. 2011, Velmurugan et al. 2012). We have previously demonstrated a robust CRFR1-mediated increase in CREB phosphorylation (Huising et al. 2010) and in the current study revealed a time- and PKA-dependent increase in IRS2 protein expression following CRFR1 activation in INS-1 cells peaking before maximum AKT activation.

CRFR1 and CRFR2 belong to the same receptor class as that of receptors for incretins, such as GLP1. GLP1 has been shown to inhibit $\beta$-cell apoptosis, and protection against cytokine-induced apoptosis was correlated with inhibition of JNK activity (Ferdaoussi et al. 2008, Natalicchio et al. 2010), but no effect was observed on p38 activity.
As for GLP1, we did not observe any effect of CRFR1 activation on p38 activity; however, we did not detect any inhibitory effect of any of the peptides on JNK phosphorylation in INS-1 cells. In MIN6 cells, TNF $\alpha$-induced JNK activation was inhibited by CRFR1 agonists (data not shown), indicating some discrepancies between the signaling in these two cell lines. In both cell types, CRFR1 ligands protected against apoptosis induced by exposure to either cytokine individually or in combination, implying that inhibition of JNK activity is not decisive for $\beta$-cell survival under these conditions. Surprisingly, cytokine-induced ERK1/2 phosphorylation was potentiated by CRFR1 agonists in INS-1 cells. Cytokine-induced ERK1/2 phosphorylation has previously been linked with cytokine-induced nitric oxide formation and $\beta$-cell apoptosis. However, ERK1/2 is generally involved in the regulation of proliferation (Blandino-Rosano et al. 2008) and our previous results indicated that OCRF-induced ERK1/2 activation was associated with increased $\beta$-cell proliferation in neonatal rat islets (Huising et al. 2010). Whether increased ERK1/2 activation following short-term exposure to cytokines acts as a survival/proliferative mechanism which is potentiated by the presence of CRFR1 agonists remains to be investigated.

Throughout the study, we observed no protective effect of the CRFR2-selective agonist UCN3 on clonal $\beta$-cells, INS-1, and MIN6. However, in intact human islets, UCN3 robustly activated AKT but did not significantly reduce apoptosis $(P=0.06)$. This is in agreement with our published observations indicating relatively low expression of CRFR2 on clonal $\beta$-cell lines as opposed to primary rodent and human islets (Huising et al. 2011). UCN3 itself is abundantly expressed in $\beta$-cells and regulates glucose-stimulated insulin secretion and energy homeostasis (Li et al. 2007). These observations strongly indicate that UCN3 plays important roles in the regulation of $\beta$-cell function in vivo. Furthermore, CRFR2 expression is robustly upregulated in both primary islets and clonal $\beta$-cells in response to glucocorticoids, increasing the sensitivity of UCN3 (Huising et al. 2010). This study also revealed that basal expression of CRFR2 is insufficient to mediate the ligand-induced response in INS-1 and MIN6 cells, but it is likely that conditions with increased CRFR2 levels would enable UCN3 to promote $\beta$-cell survival in a manner similar to agonists of CRFR1.

By testing three different batches of human islets, we consistently observed CRFR1-mediated inhibition of basal apoptosis, in line with our data on INS-1 cells. In addition, CRFR1 as well as CRFR2-signaling decreased cytokineinduced apoptosis in islets from one of the donors. Human islets from the other two donors exhibited a more robust

Published by Bioscientifica Ltd. 
induction of apoptosis in response to the combination of TNF $\alpha$, IL1 $\beta$, and IFN $\gamma$ for 6 days, and CRFR activation was not capable of protecting against cytokine-induced apoptosis in these islets (data not shown). The considerable variation in islet function and quality from preparation to preparation is a well-known concern when using human islets for experiments, indicating that additional batches of human islets and perhaps lower concentrations of or shorter exposure to cytokines are needed to explore the potential of CRF family members to protect against cytokine-induced apoptosis in human islets.

\section{Conclusion}

The results of this study indicate that CRFR1 signaling promotes $\beta$-cell survival and protects $\beta$-cells from the negative consequences of pro-inflammatory cytokines. The outcome of CRFR1-mediated signaling pathways is a shift in the balance between pro- vs anti-apoptotic signaling pathways toward increased $\beta$-cell survival. Activation of intracellular stress signaling pathways during human islet preparation has a negative effect on the prospects of the graft survival following islet transplantation (Abdelli et al. 2004, Aikin et al. 2004). The capacity of members of the CRF family to significantly reduce apoptosis in human islets following isolation indicates a therapeutic potential of these peptides in protection of islet survival. Our data prompt further analysis exploring the potential use of CRFR agonists as a therapeutic approach aimed at enhancing $\beta$-cell survival, thereby reducing or delaying cytokinemediated $\beta$-cell destruction in the development of type 1 and type 2 diabetes.

\section{Declaration of interest}

L B, G L C, M M, T M, M O H, and N B have nothing to declare. W W V was a co-founder, member of the Board of Directors, and a shareholder of Neurocrine Biosciences, a company that is developing small molecule antagonists of corticotropin-releasing factor.

\section{Funding}

This work was supported in part by The Alfred Benzon Foundation, the Clayton Medical Research Foundation, Inc., the Juvenile Diabetes Research Foundation, the National Institute of Diabetes, and Digestive and Kidney Diseases (NIDDK) grant PO1 DK026741-30, The Danish Council for Independent Research, Medical Sciences and The Novo Nordisk Foundation. G L C hold a postdoctoral grant from the Danish Diabetes Academy.

\section{Author contribution statement}

$L B$ designed the study, performed experiments, evaluated data, and wrote the manuscript. G L C performed experiments, evaluated data, and wrote the manuscript. $\mathrm{MM}, \mathrm{TM}, \mathrm{MOH}$, and $\mathrm{NB}$ evaluated data and participated in writing the manuscript, and $\mathrm{W} W \mathrm{~V}$ designed the study and evaluated data.

\section{Acknowledgements}

Human islets were obtained courtesy of the Islet cell Resource Basic Science Islets Distribution Program. The authors thank Jean Rivier and Judit Erchegyi (The Salk Institute) for providing the peptides used in this study and Helle Fjordvang for excellent technical assistance. This article is dedicated to $\mathrm{W} W \mathrm{~V}, \mathrm{PhD}$, who passed away unexpectedly on January 3 , 2012 while this work was in progress. Dr W W V was an extraordinary mentor and contributed greatly to the understanding of CRF the effects of/ urocortins in $\beta$-cells and islets.

\section{References}

Abdelli S, Ansite J, Roduit R, Borsello T, Matsumoto I, Sawada T, Allaman-Pillet N, Henry H, Beckmann JS, Hering BJ et al. 2004 Intracellular stress signaling pathways activated during human islet preparation and following acute cytokine exposure. Diabetes $\mathbf{5 3}$ 2815-2823. (doi:10.2337/diabetes.53.11.2815)

Aikin R, Maysinger D \& Rosenberg L 2004 Cross-talk between phosphatidylinositol 3-kinase/AKT and c-Jun $\mathrm{NH}_{2}$-terminal kinase mediates survival of isolated human islets. Endocrinology $1454522-4531$. (doi:10.1210/en.2004-0488)

Altarejos JY \& Montminy M 2011 CREB and the CRTC co-activators: sensors for hormonal and metabolic signals. Nature Reviews. Molecular Cell Biology 12 141-151. Review. (doi:10.1038/nrm3072)

Ammendrup A, Maillard A, Nielsen K, Aabenhus Andersen N, Serup P, Dragsbaek Madsen O, Mandrup-Poulsen T \& Bonny C 2000 The c-Jun amino-terminal kinase pathway is preferentially activated by interleukin-1 and controls apoptosis in differentiating pancreatic $\beta$-cells. Diabetes 49 1468-1476. (doi:10.2337/diabetes.49.9.1468)

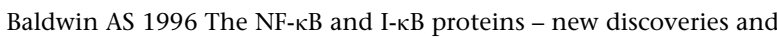
insights. Annual Review of Immunology 14 649-683. (doi:10.1146/ annurev.immunol.14.1.649)

Blandino-Rosano M, Perez-Arana G, Mellado-Gil JM, Segundo C \& Aguilar-Diosdado M 2008 Anti-proliferative effect of pro-inflammatory cytokines in cultured $\beta$ cells is associated with extracellular signal-regulated kinase $1 / 2$ pathway inhibition: protective role of glucagon-like peptide-1. Journal of Molecular Endocrinology 41 35-44. (doi:10.1677/JME-07-0154)

Bonny C, Oberson A, Steinmann M, Schorderet DF, Nicod P \& Waeber G 2000 IB1 reduces cytokine-induced apoptosis of insulin-secreting cells. Journal of Biological Chemistry 275 16466-16472. (doi:10.1074/jbc.M908297199)

Bonny C, Oberson A, Negri S, Sauser C \& Schorderet DF 2001 Cell-permeable peptide inhibitors of JNK: novel blockers of $\beta$-cell death. Diabetes 50 77-82. (doi:10.2337/diabetes.50.1.77)

Brar BK, Jonassen AK, Stephanou A, Santilli G, Railson J, Knight RA, Yellon DM \& Latchman DS 2000 Urocortin protects against ischemic and reperfusion injury via a MAPK-dependent pathway. Journal of Biological Chemistry 275 8508-8514. (doi:10.1074/jbc.275.12.8508)

Brar BK, Stephanou A, Knight R \& Latchman DS 2002 Activation of protein kinase B/Akt by urocortin is essential for its ability to protect cardiac cells against hypoxia/reoxygenation-induced cell death. Journal of Molecular and Cellular Cardiology 34 483-492. (doi:10.1006/jmcc.2002.1529)

Brubaker PL \& Drucker DJ 2002 Structure-function of the glucagon receptor family of $\mathrm{G}$ protein-coupled receptors: the glucagon, GIP, GLP-1, and GLP-2 receptors. Receptors \& Channels 8 179-188. (doi:10.1080/10606820213687)

Donath MY, Størling J, Maedler K \& Mandrup-Poulsen T 2003 Inflammatory mediators and islet $\beta$-cell failure: a link between type 1 and 
type 2 diabetes. Journal of Molecular Medicine 81 455-470. (doi:10.1007/ s00109-003-0450-y)

Elghazi L \& Bernal-Mizrachi E 2009 Akt and PTEN: $\beta$-cell mass and pancreas plasticity. Trends in Endocrinology and Metabolism 20 243-251. (doi:10.1016/j.tem.2009.03.002)

Facci L, Stevens DA, Pangallo M, Franceschini D, Skaper SD \& Strijbos PJ 2003 Corticotropin-releasing factor (CRF) and related peptides confer neuroprotection via type 1 CRF receptors. Neuropharmacology 45 623-636. (doi:10.1016/S0028-3908(03)00211-9)

Fekete EM \& Zorrilla EP 2007 Physiology, pharmacology, and therapeutic relevance of urocortins in mammals: ancient CRF paralogs. Frontiers in Neuroendocrinology 28 1-27. (doi:10.1016/j.yfrne.2006.09.002)

Ferdaoussi M, Abdelli S, Yang JY, Cornu M, Niederhauser G, Favre D, Widmann C, Regazzi R, Thorens B, Waeber G et al. 2008 Exendin-4 protects $\beta$-cells from interleukin- $1 \beta$-induced apoptosis by interfering with the c-Jun $\mathrm{NH}_{2}$-terminal kinase pathway. Diabetes 57 1205-1215. (doi:10.2337/db07-1214)

Fernández E, Martín MA, Fajardo S, Escrivá F \& Alvarez C 2007 Increased IRS- 2 content and activation of IGF-I pathway contribute to enhance $\beta$-cell mass in fetuses from undernourished pregnant rats. American Journal of Physiology. Endocrinology and Metabolism 292 E187-E195. (doi:10.1152/ajpendo.00283.2006)

Flodstrom M, Welsh N \& Eizirik DL 1996 Cytokines activate the nuclear factor $\kappa \mathrm{B}(\mathrm{NF}-\kappa \mathrm{B})$ and induce nitric oxide production in human pancreatic islets. FEBS Letters 385 4-6. (doi:10.1016/0014-5793(96)00337-7)

Florio P, Vale W \& Petraglia F 2004 Urocortins in human reproduction. Peptides 25 1751-1757. (doi:10.1016/j.peptides.2004.05.026)

Heimberg H, Heremans Y, Jobin C, Leemans R, Cardozo AK, Darville M \& Eizirik DL 2001 Inhibition of cytokine-induced NF- $\kappa$ B activation by adenovirus-mediated expression of a NF- $\mathrm{B}$ super-repressor prevents $\beta$-cell apoptosis. Diabetes 50 2219-2224. (doi:10.2337/diabetes.50.10.2219)

Hsu SY \& Hsueh AJ 2001 Human stresscopin and stresscopin-related peptide are selective ligands for the type 2 corticotropin-releasing hormone receptor. Nature Medicine 7 605-611. (doi:10.1038/87936)

Huising MO, van der Meulen T, Vaughan JM, Matsumoto M, Donaldson CJ, Park H, Billestrup N \& Vale WW 2010 CRFR1 is expressed on pancreatic $\beta$ cells, promotes $\beta$ cell proliferation, and potentiates insulin secretion in a glucose-dependent manner. PNAS 7 912-917. (doi:10.1073/pnas. 0913610107)

Huising MO, Pilbrow AP, Matsumoto M, van der Meulen T, Park H, Vaughan JM, Lee S \& Vale WW 2011 Glucocorticoids differentially regulate the expression of CRFR1 and CRFR2 $\alpha$ in MIN6 insulinoma cells and rodent islets. Endocrinology 52 138-150. (doi:10.1210/en.2010-0791)

Jhala US, Canettieri G, Screaton RA, Kulkarni RN, Krajewski S, Reed J, Walker J, Lin X, White M \& Montminy M 2003 cAMP promotes pancreatic $\beta$-cell survival via CREB-mediated induction of IRS2. Genes and Development 17 1575-1580. (doi:10.1101/gad.1097103)

Kimura Y, Takahashi K, Totsune K, Muramatsu Y, Kaneko C, Darnel AD, Suzuki T, Ebina M, Nukiwa T \& Sasano H 2002 Expression of urocortin and corticotropin-releasing factor receptor subtypes in the human heart. Journal of Clinical Endocrinology and Metabolism 87 340-346. (doi:10.1210/jcem.87.1.8160)

Kuperman Y \& Chen A 2008 Urocortins: emerging metabolic and energy homeostasis perspectives. Trends in Endocrinology and Metabolism 19 122-129. (doi:10.1016/j.tem.2007.12.002)

Lee S, Braden B, Kang SS \& Rivier C 2011 Urocortins are present in the rat testis. Neuropeptides 45 131-137. (doi:10.1016/j.npep.2010.12.006)

Lewis K, Li C, Perrin MH, Blount A, Kunitake K, Donaldson C, Vaughan J, Reyes TM, Gulyas J, Fischer W et al. 2001 Identification of urocortin III, an additional member of the corticotropin-releasing factor (CRF) family with high affinity for the CRF2 receptor. PNAS 98 7570-7575. (doi:10.1073/pnas.121165198)

Li C, Chen P, Vaughan J, Blount A, Chen A, Jamieson PM, Rivier J, Smith MS $\&$ Vale W 2003 Urocortin III is expressed in pancreatic $\beta$-cells and stimulates insulin and glucagon secretion. Endocrinology 144 3216-3224. (doi:10.1210/en.2002-0087)
Li L, El-Kholy W, Rhodes CJ \& Brubaker PL 2005 Glucagon-like peptide-1 protects beta cells from cytokine-induced apoptosis and necrosis: role of protein kinase B. Diabetologia 48 1339-1349. (doi:10.1007/s00125005-1787-2)

Li C, Chen P, Vaughan J, Lee KF \& Vale W 2007 Urocortin 3 regulates glucose-stimulated insulin secretion and energy homeostasis. PNAS 104 4206-4211. (doi:10.1073/pnas.0611641104)

Natalicchio A, De Stefano F, Orlando MR, Melchiorre M, Leonardini A, Cignarelli A, Labarbuta R, Marchetti P, Perrini S, Laviola L et al. 2010 Exendin-4 prevents c-Jun N-terminal protein kinase activation by tumor necrosis factor- $\alpha(\mathrm{TNF} \alpha)$ and inhibits TNF $\alpha$-induced apoptosis in insulin-secreting cells. Endocrinology 151 2019-2029. (doi:10.1210/en. 2009-1166)

Nikulina MA, Sandhu N, Shamim Z, Andersen NA, Oberson A, Dupraz P, Thorens B, Karlsen AE, Bonny C \& Mandrup-Poulsen T 2003 The JNK binding domain of islet-brain 1 inhibits IL-1 induced JNK activity and apoptosis but not the transcription of key proapoptotic or protective genes in insulin-secreting cell lines. Cytokine 24 13-24. (doi:10.1016/ S1043-4666(03)00242-4)

Park S, Dong X, Fisher TL, Dunn S, Omer AK, Weir G \& White MF 2006 Exendin- 4 uses Irs 2 signaling to mediate pancreatic $\beta$ cell growth and function. Journal of Biological Chemistry 281 1159-1168. (doi:10.1074/ jbc.M508307200)

Patel S \& Santani D 2009 Role of NF-к B in the pathogenesis of diabetes and its associated complications. Pharmacological Reports 61 595-603. (doi:10.1016/S1734-1140(09)70111-2)

Pavlovic D, Andersen NA, Mandrup-Poulsen T \& Eizirik DL 2000 Activation of extracellular signal-regulated kinase (ERK) $1 / 2$ contributes to cytokine-induced apoptosis in purified rat pancreatic $\beta$-cells. European Cytokine Network 11 267-274.

Perrin MH \& Vale WW 1999 Corticotropin releasing factor receptors and their ligand family. Annals of the New York Academy of Sciences $\mathbf{8 8 5}$ 312-328. (doi:10.1111/j.1749-6632.1999.tb08687.x)

Reyes TM, Lewis K, Perrin MH, Kunitake KS, Vaughan J, Arias CA, Hogenesch JB, Gulyas J, Rivier J, Vale WW et al. 2001 Urocortin II: a member of the corticotropin-releasing factor (CRF) neuropeptide family that is selectively bound by type 2 CRF receptors. PNAS 98 2843-2848. (doi:10.1073/pnas.051626398)

Saldeen J, Lee JC \& Welsh N 2001 Role of p38 mitogenactivated protein kinase (p38 MAPK) in cytokine-induced rat islet cell apoptosis. Biochemical Pharmacology 61 1561-1569. (doi:10.1016/S00062952(01)00605-0)

Schmid J, Ludwig B, Schally AV, Steffen A, Ziegler CG, Block NL, Koutmani Y, Brendel MD, Karalis KP, Simeonovic CJ et al. 2011 Modulation of pancreatic islets-stress axis by hypothalamic releasing hormones and 11ß-hydroxysteroid dehydrogenase. PNAS 108 13722-13727. (doi:10.1073/pnas.1110965108)

Schmoll D, Walker KS, Alessi DR, Grempler R, Burchell A, Guo S, Walther R \& Unterman TG 2000 Regulation of glucose-6-phosphatase gene expression by protein kinase $\mathrm{B} \alpha$ and the forkhead transcription factor FKHR. Evidence for insulin response unit-dependent and -independent effects of insulin on promoter activity. Journal of Biological Chemistry 275 36324-36333. (doi:10.1074/jbc.M003616200)

Sunayama J, Tsuruta F, Masuyama N \& Gotoh Y 2005 JNK antagonizes Akt-mediated survival signals by phosphorylating 14-3-3. Journal of Cell Biology 170 295-304. (doi:10.1083/jcb.200409117)

Van de Velde S, Hogan MF \& Montminy M 2011 mTOR links incretin signaling to HIF induction in pancreatic beta cells. PNAS $\mathbf{1 0 8}$ 16876-16882. (doi:10.1073/pnas.1114228108)

Vaughan J, Donaldson C, Bittencourt J, Perrin MH, Lewis K, Sutton S, Chan R, Turnbull AV, Lovejoy D, Rivier C et al. 1995 Urocortin a mammalian neuropeptide related to fish urotensin I and to corticotropin-releasing factor. Nature 378 287-292. (doi:10.1038/ 378287a0)

Velmurugan K, Balamurugan AN, Loganathan G, Ahmad A, Hering BJ \& Pugazhenthi S 2012 Antiapoptotic actions of exendin-4 against 
hypoxia and cytokines are augmented by CREB. Endocrinology 153 1116-1128. (doi:10.1210/en.2011-1895)

White MF 2003 Insulin signaling in health and disease. Science 302 1710-1711. (doi:10.1126/science.1092952)

Withers DJ, Burks DJ, Towery HH, Altamuro SL, Flint CL \& White MF 1999 Irs-2 coordinates Igf-1 receptor-mediated $\beta$-cell development and peripheral insulin signaling. Nature Genetics 23 32-40. (doi:10.1038/ 12631)

Zha J, Harada H, Yang E, Jockel J \& Korsmeyer SJ 1996 Serine phosphorylation of death agonist $\mathrm{BAD}$ in response to survival factor results in binding to 14-3-3 not BCL-XL. Cell 87 619-628. (doi:10.1016/S0092-8674(00)81382-3)

Received in final form 7 October 2014

Accepted 16 October 2014

Accepted Preprint published online 16 October 2014
Published by Bioscientifica Ltd. 